\title{
Dissolved oxygen in contrasting estuaries of the Bay of Biscay: effects of temperature, river discharge and chlorophyll $a$
}

\author{
Arantza Iriarte ${ }^{1, *}$, Guillermo Aravena ${ }^{1}$, Fernando Villate ${ }^{1}$, Ibon Uriarte $^{2}$, \\ Berta Ibáñez $^{3,7}$, Marcos Llope ${ }^{4,6}$, Nils Chr. Stenseth ${ }^{4,5}$ \\ ${ }^{1}$ Laboratory of Ecology, Department of Plant Biology and Ecology, Faculty of Science and Technology, \\ University of the Basque Country, PO Box 644, 48080 Bilbao, Spain \\ ${ }^{2}$ Laboratory of Ecology, Department of Plant Biology and Ecology, Faculty of Pharmacy, University of the Basque Country, \\ Paseo de la Universidad 7, 01006 Gasteiz, Spain \\ ${ }^{3}$ Basque Foundation for Health Innovation and Research (BIOEF), 48015 Sondika, Bizkaia, Spain \\ ${ }^{4}$ Centre for Ecological and Evolutionary Synthesis (CEES), Department of Biology, University of Oslo, PO Box 1066 Blindern, \\ 0316 Oslo, Norway \\ ${ }^{5}$ Flødevigen Marine Research Station, Institute of Marine Research, 4817 His, Norway \\ ${ }^{6}$ Present address: Instituto Español de Oceanografía (IEO), Centro Oceanográfico de Cádiz, Puerto Pesquero, \\ Muelle de Levante s/n, PO Box 2609, 11006 Cádiz, Andalucía, Spain \\ ${ }^{7}$ Present address: Biomedical Research Center, 31008 Pamplona, Spain
}

\begin{abstract}
The effects of environmental factors on variations of dissolved oxygen (DO) saturation was assessed in 2 estuaries (Bilbao and Urdaibai) in the Bay of Biscay with contrasting hydrography and anthropogenic impact, for the period 1997 to 2006, using generalised additive models (GAMs) and generalised additive mixed models (GAMMs). Spatial and temporal variations in DO saturation and the current severity and extent of hypoxia were higher in the culturally eutrophicated and stratified Bilbao estuary. Seasonal patterns of DO saturation and the hierarchy of factors controlling them differed both between estuaries and between salinity zones. In the inner Bilbao estuary, the main factor explaining DO-saturation variations was temperature, with a dominant effect on oxygen consumption processes. In contrast, in the outer Bilbao estuary, the main factor explaining DO-saturation variations was chlorophyll $a$, suggesting that the effect of oxygen production through photosynthesis was stronger than that of oxygen consumption. In the inner Urdaibai estuary, both a negative relationship with temperature and a positive relationship with chlorophyll a were detected. The outer Urdaibai estuary showed strong water-column mixing and very high tidal flushing, and ventilation processes were more important than oxygen production or consumption processes. River discharge affected DO saturation only at the inner waters, but when the effects of several variables on DO-saturation variability were tested in an additive model, river discharge was excluded from the models. The effects of temperature-dependent processes on DO-saturation dynamics decreased from the inner to the outer zones of both estuaries.
\end{abstract}

KEY WORDS: Dissolved oxygen $\cdot$ Chlorophyll $\cdot$ Temperature $\cdot$ River discharge $\cdot$ Estuary $\cdot$ Generalised additive models $\cdot$ Bay of Biscay

Resale or republication not permitted without written consent of the publisher

\section{INTRODUCTION}

Estuaries show strong spatial and temporal gradients in dissolved oxygen (DO) within and across ecosystems (Paerl et al. 1998, Borsuk et al. 2001, Buzzelli et al. 2002, Verity et al. 2006). Cultural eutrophication has been identified as a major process responsible for the long-term increase in hypoxic and anoxic conditions in shallow coastal and estuarine areas around the world (Diaz 2001). Enhanced oxygen consumption rates can be due to direct organic loadings from the watershed or can be caused by phytoplankton blooms (autochtho- 
nous organic matter production) fuelled by inorganic nutrient loadings (Paerl et al. 1998). It is now believed that global climate change may also lead to changes in the DO content of coastal and estuarine waters (Kemp et al. 2009). Both temperature and rainfall (primarily through its effect on river flow) appear as dominant drivers of seasonal DO variations in many of these systems. Minimum DO levels are frequently registered during the summer (Welsh \& Eller 1991, Buzzelli et al. 2002, Rabalais et al. 2002, Breitburg et al. 2003). Temperature increases can promote bottom-water oxygen depletion, as a consequence of water-column thermal stratification (Welsh \& Eller 1991). In addition, temperature can have direct effects on biological processes of oxygen consumption and production. Temperature enhances rates of planktonic and benthic respiration rates (Kemp et al. 1992, Sampou \& Kemp 1994), but primary production is also intensified in summer in many temperate estuarine zones (Boynton et al. 1982), although an accumulation of phytoplankton biomass could subsequently promote bottom-water oxygen depletion.

River flow has also been reported to play a paramount influence on seasonal DO dynamics in some nearshore coastal and estuarine systems. Intensification of salinity stratification by high freshwater inflows during the spring has been shown to be the key parameter contributing to low levels of DO during spring and summer in some systems (Wiseman et al. 1997). However, a stratified water column is not a necessary condition for the development of hypoxia, which has been shown to occur in well-mixed eutrophic estuaries (Verity et al. 2006). Furthermore, very high river discharges can lower the intensity of stratification (Howarth et al. 2000) and cause DO replenishment in some estuarine zones. In addition, river flow can also affect seasonal DO variations by its influence on water residence time (see Rabalais et al. 2002).

It is clear that climate and eutrophication can affect DO variations in different ways depending on estuarine typology (geomorphology and hydrography) and, therefore, the relationships between these factors are site-specific (Kemp et al. 2009) and the mechanisms that control low dissolved-oxygen levels are often difficult to establish (Nezlin et al. 2009). DO is a key parameter in the assessment of the ecological status of estuarine and coastal waters, a requirement of the European Water Framework Directive. To be able to discern between the contribution of climate and that of eutrophication to variations in DO is a key challenge that needs to be resolved for the implementation of appropriate management plans in systems that undergo hypoxia/anoxia events.

The Bilbao and Urdaibai estuaries are located in close proximity of one another on the Basque coast (Bay of Biscay). They share the same climate, but they show important differences in hydrography and the degree of anthropogenic impact, which has led to differences in the ecological status of these estuaries. Differences in these 2 factors are not only observed between the estuaries, but also along the longitudinal axis within each estuary. The aim of the present work was to assess the contribution of climate variables and eutrophication to seasonal and axial DO (expressed as saturation values) variations along the longitudinal salinity gradient of these contrasting estuaries. In these estuaries water temperature and river flow have been shown to be significantly and positively correlated to air temperature and rainfall, respectively, (Aravena et al. 2009), and the former were used in the present study as proxies for the latter. In addition, chlorophyll a (chl a) was taken as indicator of eutrophication. We estimated this contribution by analysing time-series (1997 to 2006) of water temperature, river flow, chl a and DO saturation in the Bilbao and Urdaibai estuaries using generalised additive models (GAMs) and generalised additive mixed models (GAMMs). The assessment of ecological responses to environmental changes is often complex due to non-linear relationships between variables. GAMs (and GAMMs) provide nonparametric alternatives when the relationship between the response variable and the predictors is non-linear and parametric relationships are not obvious (Borsuk et al. 2001, Zuur et al. 2007). In addition, they are able to minimise the effects of extreme observations and they often provide a more reasonable ecological explanation to data (Wood 2006).

\section{MATERIALS AND METHODS}

Study area. The Bilbao and Urdaibai estuaries are located on the Basque coast, at middle latitudes of the northeastern Atlantic (Fig. 1). The climate of the area is temperate-oceanic with moderate winters and warm summers (Usabiaga et al. 2004), showing a variable distribution of precipitation and, to a lesser extent, of temperature.

The urban Bilbao estuary $\left(43^{\circ} 23^{\prime} \mathrm{N} 3^{\circ} \mathrm{W}\right)$ (Fig. 1) is a macrotidal system constituted by a narrow (50 to $150 \mathrm{~m})$, ca. $15 \mathrm{~km}$ long, 2 to $9 \mathrm{~m}$ deep man-made channel that crosses urban and industrial areas and a wider (ca. $3.8 \mathrm{~km}$ ) and deeper (10 to $25 \mathrm{~m}$ ) embayment. Most of the estuary shows an important water-column stratification (see Fig. 2) and a permanent salt wedge is found in the bottom layer, where salinities are usually $\geq 30$ (Valencia et al. 2004). The water column is partially mixed at the outer estuary, partially mixed to stratified at the intermediate zone and stratified at the inner estuary (see Urrutia 1986). It would take around 2 mo to infill the mean volume of the estuary $(200 \times$ 
$10^{6} \mathrm{~m}^{3}$ ) with the mean river flow (Valencia et al. 2004). In the last $\sim 150$ yr this estuary has received large amounts of pollutants from many sources (mineral sluicing, industrial wastes and urban effluents), which have significantly impoverished its water quality (Belzunce et al. 2004), giving rise to extended periods of hypoxia and even anoxia events in the inner estuary (Iriarte et al. 1998, Borja et al. 2006). During the last few decades, industrial decline and the development of urban wastewater treatment plants (Fig. 1) in the area have caused a decrease of pollutant inputs to the estuary. However, organic matter and inorganic nutrient inputs are still high (García-Barcina et al. 2006), rendering the system eutrophic (Butrón et al. 2009). In waters below the halocline, which are the ones sampled in the present study, salinity decreases from the outer to the inner estuary. Together with this axial decreasing gradient in salinity in waters below the halocline, there is also an axial increasing gradient in pollution (e.g. increases in $\mathrm{NH}_{3}$ and decreases in DO) (Iriarte et al. 1998, García-Barcina et al. 2006).
González-Oreja \& Saiz-Salinas (1998) suggested that the low levels of oxygen in the inner Bilbao estuary were mainly responsible for the establishment of simpler macrobenthic communities, i.e. with low abundance, diversity and evenness values and very low biomass, compared to other zones of the estuary with higher bottom-water oxygen levels. Prior to the mid1990s there were areas of persistent anoxic conditions with azoic sediments. The macrobenthic communities have been subject to a slow and moderate recovery in the last $15 \mathrm{yr}$ or so (Borja et al. 2006). Overall, the ecological status of the inner estuary (corresponding to the sampling site called '30 salinity' in the present work) has been described as bad, that of the intermediate estuary (sampling site called '33 salinity' in the present work) as poor and that of the outer estuary (sampling site called ' $\geq 34$ salinity' in the present work) as moderate (Franco et al. 2004). Subtidal sediments are muddy sands along the entire estuary, with highest mud (45 to $50 \%$ on average) and organic matter (9 to $12 \%$ on average) contents in the intermediate zone, and lowest



Fig. 1. Location of the Bilbao (left) and Urdaibai (right) estuaries. The approximate extent of the salinity zones at high tide are shown. Abusu and Muxika are the hydro-meteorological stations. WWTP: wastewater treatment plant 
mud (15 to $30 \%$ on average) and organic matter (3 to $11 \%$ on average) contents in the outer zone (Cotano \& Villate 2006).

The Urdaibai estuary $\left(43^{\circ} 22^{\prime} \mathrm{N}, 2^{\circ} 43^{\prime} \mathrm{W}\right)$ is also a short $(12.5 \mathrm{~km})$ meso-macrotidal system, but shallower (mean depth of $3 \mathrm{~m}$ ) than the Bilbao estuary. The central channel is bordered by salt marshes at its upper (15 $\mathrm{m}$ wide) and middle reaches and by relatively extensive intertidal flats (mainly sandy) and sandy beaches at its lower reaches (ca. $1 \mathrm{~km}$ wide). The watershed area is relatively small in relation to the estuarine basin, and river inputs are usually low in relation to the tidal prism. As a consequence, most of the estuary is marine-dominated, with high-salinity waters in the outer half and a stronger, decreasing axial gradient of salinity towards the head, where it receives most of the freshwater inputs from its main tributary. It has been estimated that it would take around $10 \mathrm{~d}$ to infill the mean volume of the estuary $\left(3.29 \times 10^{6} \mathrm{~m}^{3}\right)$ with the mean river flow (Valencia et al. 2004). In the upper reaches, the estuary receives inputs of inorganic nutrients and organic matter, and in this area (corresponding to sampling site '30 salinity' in the present work) the ecological status of the estuary has been described as poor (Franco et al. 2004), whereas in the outer zone, tidal flushing is high, to the extent that waters of salinities $>34$ are flushed out of the estuary with each tidal cycle (Villate et al. 1989) and the ecological status of this estuarine area (corresponding to sampling site ' $\geq 34$ salinity' in the present work) has been described as good (Franco et al. 2004). The intermediate zone can be considered to be of moderate ecological status (sampling site '33 salinity' in the present work). The outer area of the estuary remains well mixed most of the time (sampling site of $\geq 34$ salinity in the present work), and the inner half is more stratified (sampling sites of 33 and 30 salinity in the present work are partially mixed zones). Subtidal sediments are exposed sands in the outer zone and muddy sands in the intermediate and inner zones, with lower mud ( $<1 \%$ on average) and organic matter ( 1 to $2 \%$ on average) contents in the outer zone, higher mud (around $45 \%$ on average) content in the intermediate zone, and higher organic matter ( 3 to $7 \%$ on average) content in the intermediate and inner zones (Cotano \& Villate 2006).

Sampling and data set acquisition. Estuarine water samplings were carried out once a month, at high tide, from 1997 to 2006 in 3 selected salinity zones (zones in which at ca. mid-depth, below the halocline there are waters of salinities of $30 \pm 1,33 \pm 0.5$ and $\geq 34$ in the Bilbao and Urdaibai estuaries; see Fig. 1). At each sampling point (1 per salinity region), vertical profiles of salinity, water temperature and DO saturation were obtained in situ using a multi 350i Multi-Parameter
Water Quality Meter (WTW; accuracy - salinity: \pm 0.2 , temperature: $\pm 0.3^{\circ} \mathrm{C}$ and DO saturation: \pm 0.5 of the measurement). The instrument was calibrated prior to each sampling according to standard calibration procedures recommended by the manufacturer. In addition, at each sampling point, the Secchi disk depth was measured, and water samples were collected for chl a analysis from below the halocline. In the 30 salinity zone, sampling commenced in 1999. Chl a was measured spectrophotometrically in triplicate samples according to the monochromatic method with acidification (Jeffrey \& Mantoura 1997). Chl a concentrations were transformed to $\log (x+1)$ values to achieve homogeneity of variance.

Monthly mean values of river discharge for the study period measured at the hydro-meteorological stations of Abusu and Muxika, for the Bilbao and Urdaibai estuaries respectively, were obtained from the County Council of Bizkaia (www.bizkaia.net/Ingurugiroa_Lurraldea/ Hidrologia_Ac/Datos.asp?Tem_Codigo=2781).

The water temperature, salinity and DO saturation values used in the statistical analyses correspond only to those measured for waters below the halocline for which chl a concentrations were also measured.

Statistical analyses. Pretreatment of data: Missing data were interpolated using the Tramo-Seats package incorporated in the Demetra 2.0 interface, according to the methodology described by Gómez \& Maravall (1994) and Gómez et al. (1999). The method used for interpolation was the additive outlier (AO) approach with correction in the Determinantal Term of the Likelihood (see Gómez \& Maravall 1994). Given that the number of missing observations was not high (about $10 \%$ ), this method gave similar results to the skipping approach, and the former was used following suggestions by Gómez \& Maravall (1994).

GAMs and GAMMs: The time-series data were analysed using GAMs (Hastie \& Tibshirani 1990), as implemented in the mgcv library of R (Wood 2000). GAMs are non-parametric regression techniques that allow for the modelling of relationships between variables without specifying any particular form for the underlying regression function. This is achieved by fitting smooth additive functions (splines) for each covariate included in the model structure. More precisely, for data with $p$ covariates $\left\{\left(y_{i i} x_{i 1}, \ldots, x_{i p}\right) ; i=1, \ldots\right.$, $\mathrm{n}$ ) and response assumed to be Gaussian, the general form of a GAM is given by

$$
y_{i}=\alpha+\sum_{j=1}^{p} s_{j}\left(x_{i j}\right)+\varepsilon_{i}
$$

where the $j$ th covariate has its own associate component $\mathbf{s}_{j}$ and the regression function is constructed from the combination of these components; alpha is a constant in the regression. The smooth functions $\mathrm{s}_{j}(x)$ 
used here are penalised regression splines. The model is estimated by penalised iteratively reweighted least squares (P-IRLS), with smoothing parameters estimated by optimising the generalised cross-validation (GCV) criterion (Wood 2000), allowing for a trade-off between the goodness of fit and the smoothness of the functions.

The GAM estimation procedure assumes that the errors $\varepsilon_{\mathrm{i}}$ are independent, but temporal series are usually subject to temporal autocorrelation. GAMMs incorporate the correlation structure in the covariance matrix of the error term (for further details see Wood 2000,2006 ) and they were used when autocorrelation was present. To take into account these particularities, we carried out the model fitting for the data following 3 steps. Model selection was based on a step-wise approach, aimed at removing covariates with a p-value $>0.05$ and minimising the GCV criterion of the model. Next, the assumed independence structure in the error term was checked using both the autocorrelation function $(\mathrm{ACF})$ and the partial autocorrelation function (PACF). Finally, in those cases where autocorrelation was significant, an appropriate process according to the ACF and PACF, such as AR(1), the autoregressive process of order $p=1$ was assumed, and the diagnosis of the model was carried out on the final model to check if the error term could be assumed to be white noise. The functional relationship was graphically explored to interpret the relationships, and the goodness of fit given by the $\mathrm{R}^{2}$ was used to summarise the variability explained. All analyses were carried out using R 2.5.1, with the library $\mathrm{mgcv}_{\text {, and }}$ significance was set at $\alpha=0.05$.

\section{RESULTS AND DISCUSSION}

\section{Vertical temperature and salinity gradients and eutrophication characteristics}

In the Bilbao estuary, as in many other estuaries (Park et al. 2007, Nezlin et al. 2009), salt stratification was markedly stronger than thermal stratification at all sampling sites and seasons and, in agreement with results from Urrutia (1986), the strength of stratification increased longitudinally from the outer to the inner estuary (Table 1, Fig. 2). At the inner estuary the water column was salinity-stratified throughout the whole annual cycle (Fig. 2). This estuary showed a significant degree of turbidity. Seasonal mean Secchi disk depth values ranged from 0.8 to $1.4 \mathrm{~m}$ in the inner and intermediate estuaries, and higher values, ca. 2 to $2.7 \mathrm{~m}$, were registered in the $\geq 34$ salinity zone (Table 1 ). Chl a values peaked in summer in all sampling zones, and the most turbid intermediate and inner estuary were also the zones of highest chl a values, suggesting a higher degree of eutrophication in the inner and intermediate estuarine zones.

In agreement with previous results (Villate et al. 1989, Valencia et al. 2004), we observed that in the sampling zones of the Urdaibai estuary, stratification was weaker than in the Bilbao estuary (Table 1, Fig. 2). Furthermore, in the outer estuary ( $\geq 34$ salinity zone) of Urdaibai the water column was generally well mixed. However, as in the Bilbao estuary, salt stratification was stronger than thermal stratification (Table 1, Fig. 2). In the Urdaibai estuary, turbidity was lower

Table 1. Characteristics of sampling sites in the Bilbao and Urdaibai estuaries. Values are seasonal means for the time-series (1997 to 2006). Percentage of organic matter (\%OM) in sediments are from Cotano \& Villate (2006) and correspond to sampling sites for subtidal sediments of the same zones of the sampling sites of the present study. A: autumn, Sp: spring, Su: summer, W: winter

\begin{tabular}{|c|c|c|c|c|c|c|c|}
\hline \multirow[t]{2}{*}{ Variable } & \multirow[t]{2}{*}{ Season } & \multicolumn{3}{|c|}{$\begin{array}{l}\text { Bilbao estuary } \\
\text { Salinity zone }\end{array}$} & \multicolumn{3}{|c|}{$\begin{array}{l}\text { Urdaibai estuary } \\
\text { Salinity zone }\end{array}$} \\
\hline & & 30 & 33 & $\geq 34$ & 30 & 33 & $\geq 34$ \\
\hline $\begin{array}{l}\text { Surface } \\
\text { salinity }\end{array}$ & $\begin{array}{c}\text { W } \\
\mathrm{Sp} \\
\mathrm{Su} \\
\mathrm{A}\end{array}$ & $\begin{array}{c}3.00 \\
3.69 \\
10.18 \\
7.54\end{array}$ & $\begin{array}{c}7.49 \\
10.23 \\
17.87 \\
13.18\end{array}$ & $\begin{array}{l}18.46 \\
23.89 \\
30.76 \\
26.34\end{array}$ & $\begin{array}{l}21.95 \\
25.24 \\
28.92 \\
26.09\end{array}$ & $\begin{array}{l}26.60 \\
30.06 \\
32.27 \\
30.23\end{array}$ & $\begin{array}{l}33.19 \\
33.80 \\
34.32 \\
33.79\end{array}$ \\
\hline $\begin{array}{l}\text { Bottom } \\
\text { salinity }\end{array}$ & $\begin{array}{c}\mathrm{W} \\
\mathrm{Sp} \\
\mathrm{Su} \\
\mathrm{A}\end{array}$ & $\begin{array}{l}31.02 \\
31.40 \\
31.09 \\
31.16\end{array}$ & $\begin{array}{l}33.48 \\
33.56 \\
33.47 \\
33.51\end{array}$ & $\begin{array}{l}34.82 \\
34.87 \\
34.71 \\
34.84\end{array}$ & $\begin{array}{l}30.61 \\
30.83 \\
30.70 \\
30.88\end{array}$ & $\begin{array}{l}33.39 \\
33.48 \\
33.23 \\
33.54\end{array}$ & $\begin{array}{l}34.73 \\
34.80 \\
34.65 \\
34.83\end{array}$ \\
\hline $\begin{array}{l}\text { Surface } \\
\text { temperature }\left({ }^{\circ} \mathrm{C}\right)\end{array}$ & $\begin{array}{c}\mathrm{W} \\
\mathrm{Sp} \\
\mathrm{Su} \\
\mathrm{A}\end{array}$ & $\begin{array}{c}9.28 \\
16.15 \\
22.14 \\
16.00\end{array}$ & $\begin{array}{c}9.86 \\
16.82 \\
22.00 \\
15.59\end{array}$ & $\begin{array}{l}10.89 \\
15.79 \\
21.11 \\
16.34\end{array}$ & $\begin{array}{l}10.63 \\
15.79 \\
22.89 \\
16.13\end{array}$ & $\begin{array}{l}10.75 \\
15.88 \\
22.19 \\
15.94\end{array}$ & $\begin{array}{l}11.93 \\
15.24 \\
21.38 \\
16.50\end{array}$ \\
\hline $\begin{array}{l}\text { Bottom } \\
\text { temperature }\left({ }^{\circ} \mathrm{C}\right)\end{array}$ & $\begin{array}{c}\text { W } \\
\mathrm{Sp} \\
\mathrm{Su} \\
\mathrm{A}\end{array}$ & $\begin{array}{l}12.27 \\
14.65 \\
20.67 \\
17.21\end{array}$ & $\begin{array}{l}12.57 \\
14.77 \\
20.53 \\
16.98\end{array}$ & $\begin{array}{l}12.67 \\
14.42 \\
20.00 \\
16.83\end{array}$ & $\begin{array}{l}11.42 \\
15.59 \\
22.63 \\
16.37\end{array}$ & $\begin{array}{l}11.69 \\
15.44 \\
21.93 \\
16.28\end{array}$ & $\begin{array}{l}12.29 \\
14.99 \\
21.18 \\
16.66\end{array}$ \\
\hline $\begin{array}{r}\text { Secchi disk } \\
\text { depth }(\mathrm{m})\end{array}$ & $\begin{array}{c}\text { W } \\
\text { Sp } \\
\text { Su } \\
\text { A }\end{array}$ & $\begin{array}{l}0.82 \\
1.19 \\
0.99 \\
1.07\end{array}$ & $\begin{array}{l}1.28 \\
1.29 \\
1.28 \\
1.43\end{array}$ & $\begin{array}{l}2.50 \\
2.01 \\
2.65 \\
2.74\end{array}$ & $\begin{array}{l}1.73 \\
1.68 \\
1.53 \\
1.61\end{array}$ & $\begin{array}{l}2.24 \\
2.43 \\
1.98 \\
2.01\end{array}$ & $\begin{array}{l}3.06^{\mathrm{a}} \\
3.75^{\mathrm{a}} \\
3.42^{\mathrm{a}} \\
3.78^{\mathrm{a}}\end{array}$ \\
\hline $\begin{array}{l}\mathrm{Chl} a \\
\quad\left(\mu \mathrm{gl}^{-1}\right)\end{array}$ & $\begin{array}{c}\text { W } \\
\mathrm{Sp} \\
\mathrm{Su} \\
\mathrm{A}\end{array}$ & $\begin{array}{l}0.73 \\
3.24 \\
8.98 \\
2.83\end{array}$ & $\begin{array}{l}0.79 \\
2.30 \\
6.96 \\
1.50\end{array}$ & $\begin{array}{l}0.47 \\
2.17 \\
5.58 \\
1.66\end{array}$ & $\begin{array}{l}1.02 \\
4.70 \\
8.86 \\
1.66\end{array}$ & $\begin{array}{l}0.78 \\
2.32 \\
4.02 \\
1.08\end{array}$ & $\begin{array}{l}0.61 \\
1.23 \\
0.75 \\
0.74\end{array}$ \\
\hline$\% \mathrm{OM}$ in sediment & & 8.65 & 8.98 & 6.81 & 4.25 & 4.03 & 1.55 \\
\hline
\end{tabular}



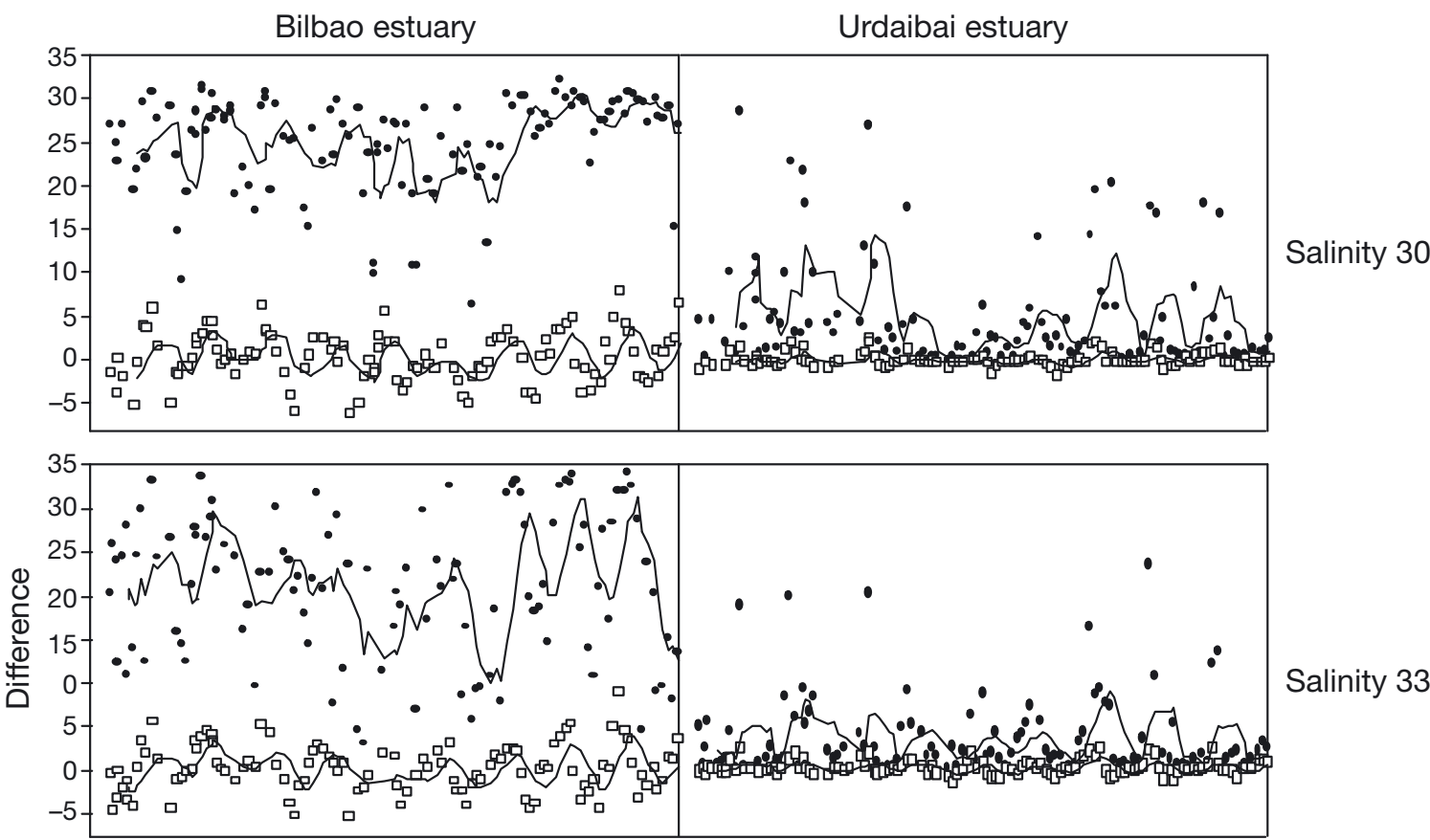

Salinity 33

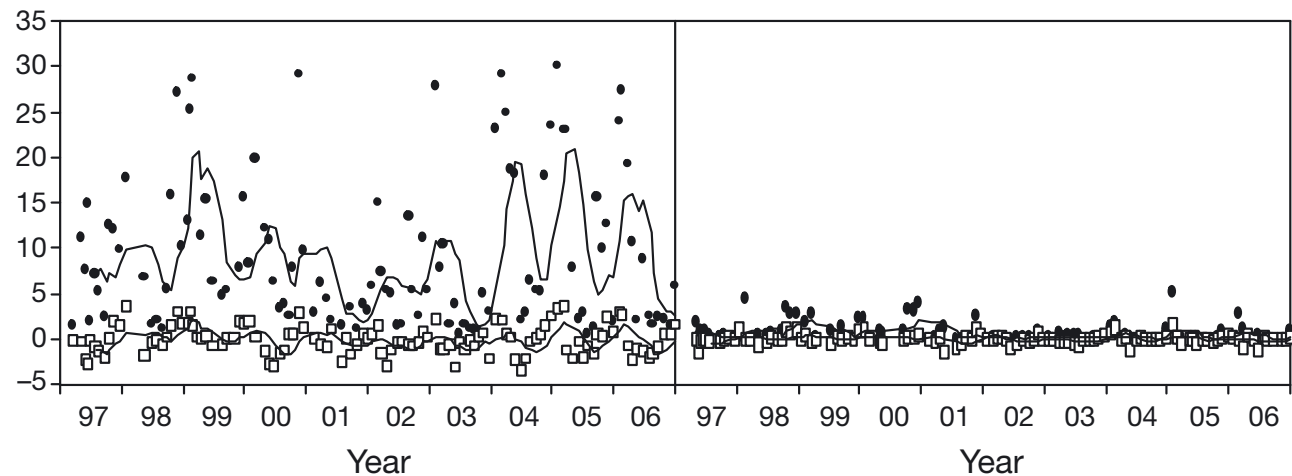

Fig. 2. Vertical difference (bottom - surface) in salinity $(\bullet)$ and temperature $\left({ }^{\circ} \mathrm{C}_{i}\right.$ ㅁ) in the 30,33 and $\geq 34$ salinity sampling zones (upper, middle and lower panels respectively) in the Bilbao (left panels) and Urdaibai (right panels) estuaries during 1997 to 2006. Moving averages are also shown (-)

than in the Bilbao estuary, particularly at the outer estuary, where the Secchi disk was frequently seen to reach the bottom (Table 1). Chl a concentrations were also generally lower in the Urdaibai than in the Bilbao estuary, showing the largest difference at the outer estuary, where mean seasonal values $<1.3 \mu \mathrm{g} \mathrm{l}^{-1}$ were measured in the Urdaibai estuary (Table 1). In agreement with these observations, the percentage organic matter in sediments in the Urdaibai estuary was lower than in the Bilbao estuary and on a longitudinal scale it was markedly lower in the outer estuary than in the intermediate and inner estuary (Cotano \& Villate 2006; see our Table 1). Turbidity, percentage organic matter and chl a values indicate a lower degree of eutrophication, and a stronger decrease of the eutrophic condition towards the outer estuary in the Urdaibai than in the Bilbao estuary.

\section{Axial and/or seasonal variations in water temperature, river discharge and DO saturation}

Water temperature, river discharge and DO-saturation variations during the study period are shown in Fig. 3 and their seasonal patterns are depicted in Fig. 4.

Water temperature showed a typical seasonal pattern for temperate regions, with maxima in summer and minima in winter in both estuaries and all salinity zones. However, seasonal and axial variations were more marked in the Urdaibai than in the Bilbao estuary. These differences in water temperature between estuaries can be due to the fact that the Urdaibai estuary is shallower and is better flushed than the Bilbao estuary (Valencia et al. 2004, Aravena et al. 2009). The main axial differences in both estuaries were related to the range of temperatures and the immediacy of response 
to air temperature (Aravena et al. 2009). The inner waters showed higher summer maxima and lower winter minima, and they also showed faster spring warming and autumn cooling than the outer waters.

River discharge was much higher in the Bilbao than in the Urdaibai estuary, but seasonal and inter-annual variations were similar in both estuaries, with higher values in winter and lower in summer, except for the anomalous year 2002. According to the annual cycle of river discharge (Fig. 4), the highest values were recorded from December to February and the lowest values in September in both estuaries.

DO saturation in subhalocline waters of the euhaline portion of the Bilbao estuary was, on average, lower than in subhalocline waters of analogous salinity in the Urdaibai estuary (mean \pm SD of 3 salinity sites' pooled DO-saturation values was $67.9 \pm 30.4$ and $90.9 \pm 13.2 \%$ for the Bilbao and Urdaibai estuaries respectively). Various factors can potentially contribute to this difference in DO saturation. First, the Bilbao estuary receives much higher urban wastewater inputs $\left(350000 \mathrm{~m}^{3} \mathrm{~d}^{-1}\right.$ of treated wastewater from the metro- politan area of Bilbao with ca. 900000 inhabitants) than the Urdaibai estuary (26000 to $38000 \mathrm{~m}^{3} \mathrm{~d}^{-1}$ of treated wastewater from an area with a population density < 45000$)$. In agreement with this, as mentioned above ('Results and discussion: Vertical temperature and salinity gradients and eutrophication characteristics'), the organic matter content of sediments is higher in the Bilbao than in the Urdaibai estuary (Cotano \& Villate 2006). In addition, in the euhaline region of the Bilbao estuary, stratification is, on average, much higher (Table 1, Fig. 2) and residence time is longer than in the euhaline region of the Urdaibai estuary (Villate et al. 1989, Valencia et al. 2004).

Axial variations in DO saturation were evident in both estuaries, but they were much more marked in the estuary of Bilbao. In this system, during spring and summer, DO saturation showed a marked outer-toinner decreasing gradient, reaching hypoxic conditions in the 30 salinity zone. In most years studied, during most months of the year, DO-saturation values were $<40 \%$, frequently reaching values as low as $<5 \%$ during summer months in the inner Bilbao estuary. In
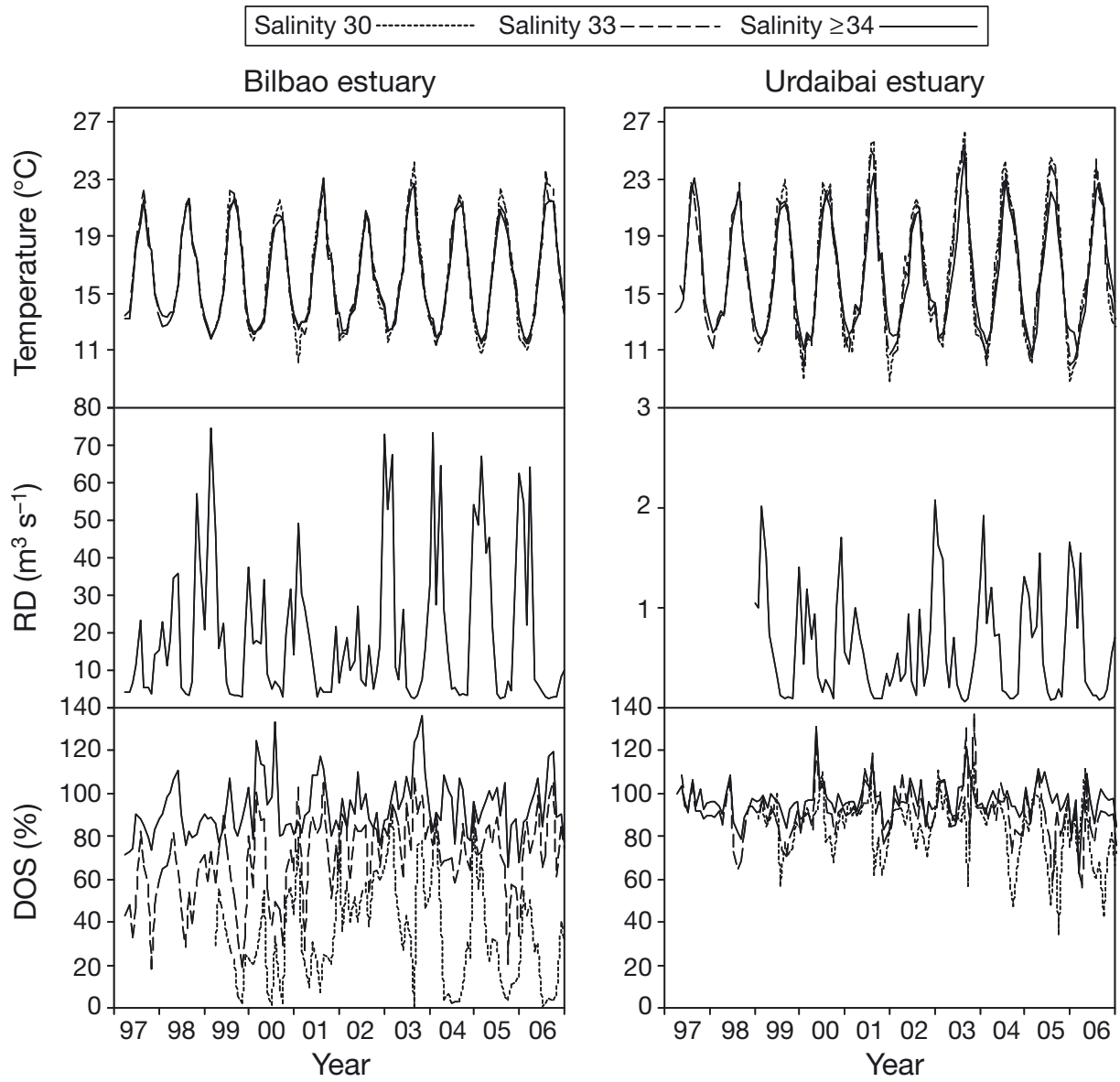

Fig. 3. Monthly time-series for water temperature (upper panels), river discharge (RD; middle panels) and dissolved oxygen saturation (DOS; lower panels) in the Bilbao (left panels) and Urdaibai (right panels) estuaries from 1997 to 2006. Water temperature and DOS are shown for each of the salinity zones under study 
some years, even winter values were $<45 \%$, revealing that low DO-saturation conditions were not always restricted to summer in this inner zone of the Bilbao estuary. This shows the importance of studying wholeyear DO-saturation dynamics in some estuarine systems. In the inner Bilbao estuary, hypoxia has caused a significant impoverishment of benthic communities, which show low biomass and a disturbed community structure where opportunistic species are dominant (Borja et al. 2006); this impoverishment was even more profound (there were areas with azoic sediments) prior to the 1990s, when hypoxic/anoxic conditions were more severe than today (González-Oreja \& SaizSalinas 1998).

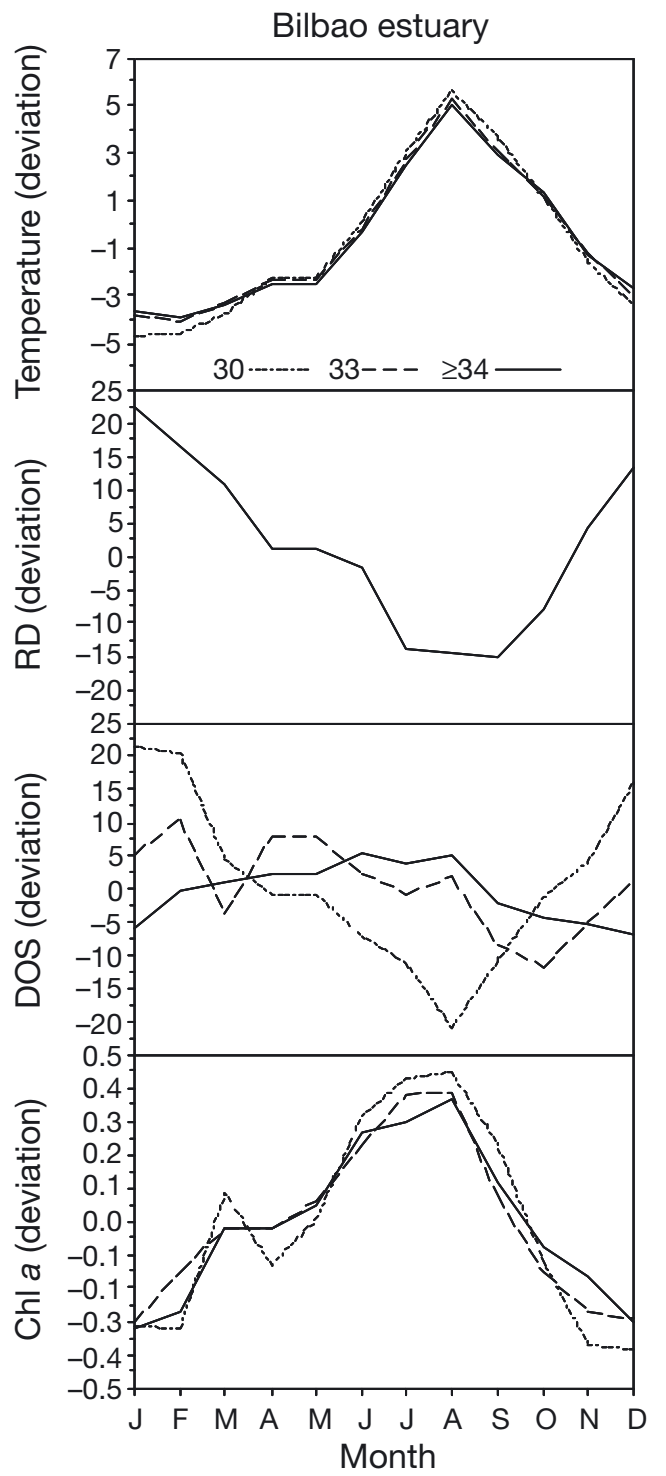

In the Urdaibai estuary, the outer-to-inner decrease of DO saturation was less marked; it was restricted to a shorter period, and no hypoxic conditions were recorded. Previous studies in the estuary of Bilbao (Iriarte et al. 1998, Valencia \& Franco 2004, Borja et al. 2006, García-Barcina et al. 2006) and Urdaibai (Franco et al. 1996, Iriarte et al. 1997) also reported axial outer-to-innerestuary decreasing gradients in bottom-water DO, and similar spatial patterns have been described for other estuaries (Kuo et al. 1991, Breitburg et al. 2003). The spatial variations (between estuaries and within an estuary) in DO saturation are in agreement with the overall assessment of these estuarine zones in terms of their ecological status: bad for the inner estuarine zone and

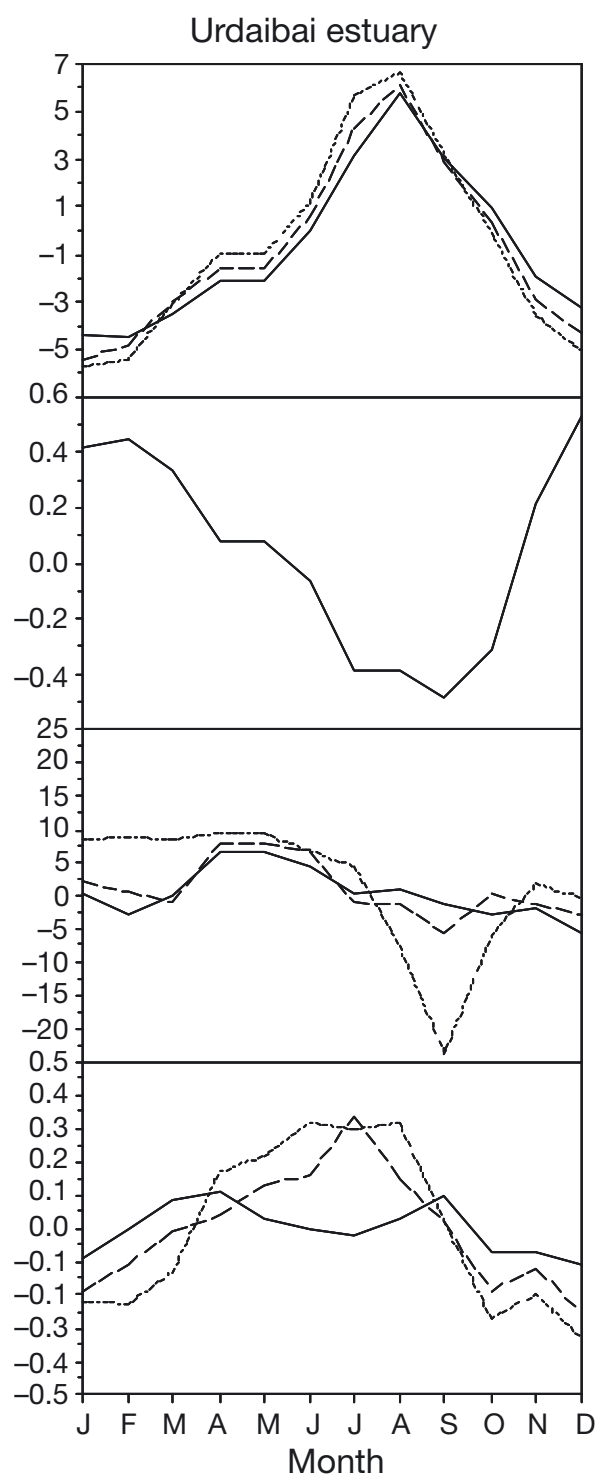

Fig. 4. Seasonal variation (in terms of deviation) of water temperature (upper row), river discharge (RD; 2nd row), dissolved oxygen saturation (DOS; 3rd row) and chl a (bottom row) in each salinity zone in the Bilbao (left panels) and Urdaibai (right panels) estuaries. Deviations were calculated as follows: the mean value for the whole series was obtained and the deviation (difference) from this series mean was calculated for each monthly value; finally, the mean deviation for each month was obtained 
moderate for the outer embayment of the Bilbao estuary, and moderate and good for the inner and outer zones of the Urdaibai estuary (Franco et al. 2004). Our data further showed that the seasonal pattern of DO saturation varied along the salinity gradient we sampled in both estuaries (Fig. 4). In the Bilbao estuary, in the inner zone, DOsaturation values fluctuated largely from winter maxima to summer minima, whereas in the outer zone seasonal DO-saturation variations were much smaller, and annual maxima were observed during summertime. In the Urdaibai estuary, in the inner zone, minimum DOsaturation values were measured in late summer-early autumn and maxima in winter-spring. In the intermediate-salinity zone, minimum values were also registered in late summer-early autumn, but variations along the annual cycle were much smaller and maxima occurred in spring. In the outer estuary, on average, DOsaturation values were also higher during springtime, but they were always around $100 \%$ saturation and showed very small variations throughout the annual cycle.

\section{Axial and seasonal variations in chl a concentration}

Chl a variations during the study period are shown in Table 1 and Fig. 5, and the seasonal deviations from the time-series mean are depicted in Fig. 4. In the euhaline region of the Bilbao estuary, differences in chl a concentration among salinity zones were small, whereas in the euhaline waters of the Urdaibai estuary, chl a values were similar to those of the Bilbao estuary in the inner salinity zone, but decreased markedly from the inner to the outer salinity zones. The seasonal pattern of chl a concentration also showed important differences (Fig. 4). In the Bilbao estuary, seasonal maxima were observed in summer in all salinity zones, although a first smaller annual peak was registered in late winter-early spring in the inner salinity zone. In the Urdaibai estuary the seasonal pattern showed clear axial differences. Chl a maxima were registered during the summer at salinities of 30 and 33, whereas at the outer estuary (salinity $\geq 34$ ) the seasonal distribution was bimodal, with peaks during the spring and late summer-early autumn, and lower values during the summer. In nearshore coastal and estuarine waters there is large variability in the seasonal pattern of phytoplankton biomass across and within ecosystems (Cloern \& Jassby 2008, Butrón et al. 2009) and, to a large extent, this is the result of the large heterogeneity in geomorphological and hydrographical features (Butrón et al. 2009). To explain the different seasonal pattern in the outer estuary of Urdaibai, in previous works (Iriarte et al. 1997, Villate et al. 2008) we argued that in this zone, high tidal flushing causes

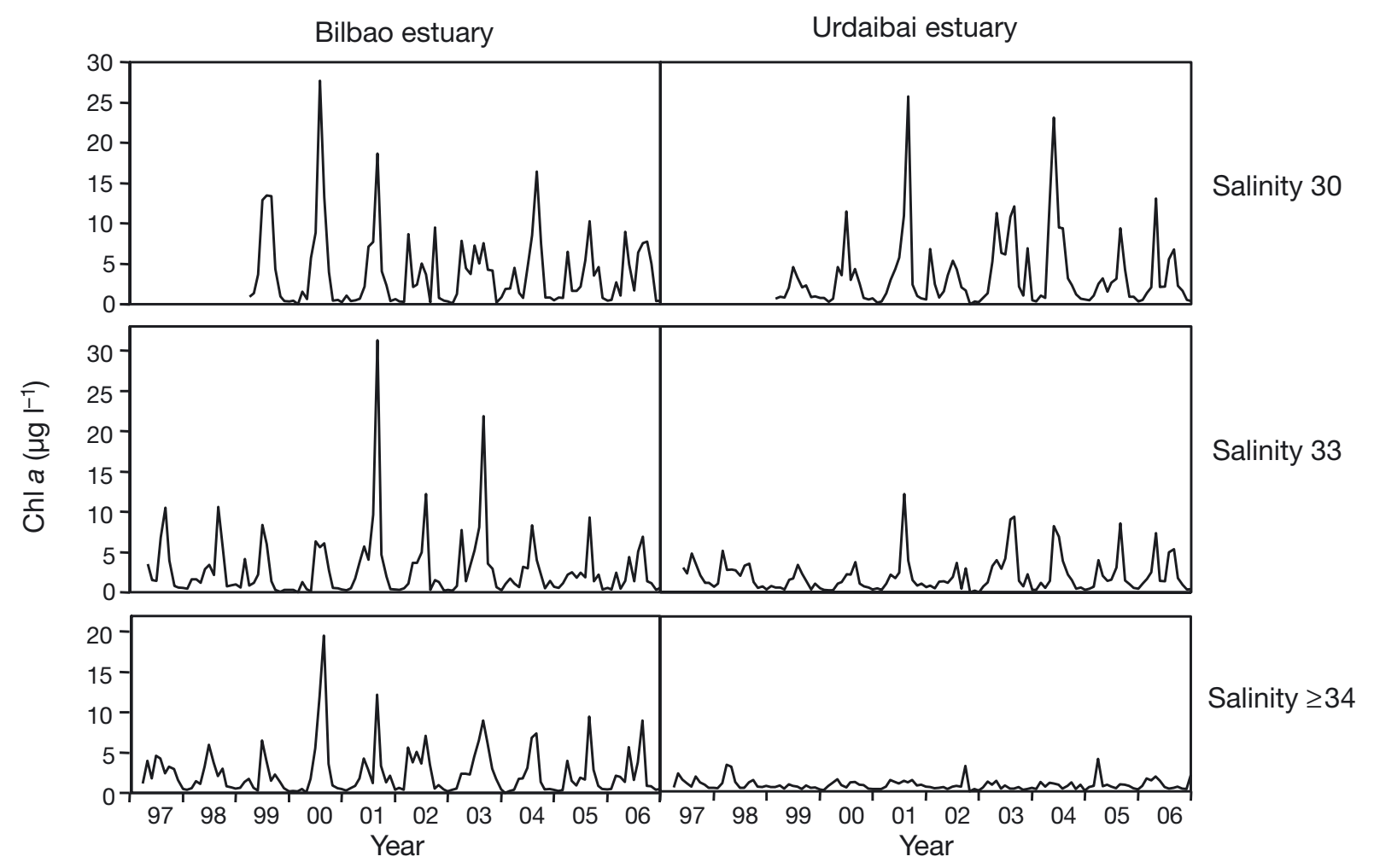

Fig. 5. Monthly time series of the concentration of chlorophyll $a$ in each salinity zone $(30,33$ and $\geq 34$; upper, middle and lower panels respectively) in the Bilbao (left panels) and Urdaibai (right panels) estuaries from 1997 to 2006 
nutrient concentrations to reach limiting levels for phytoplankton production during the summer.

\section{Effects of temperature and chl a on DO saturation}

The results of the statistical models (GAMs and GAMMs) that were built taking into account the effect of different variables in an additive fashion are shown in Table 2 and Figs. 6 \& 8 .

Both water temperature and chl a concentration were found to affect DO saturation in a different way depending on the salinity zone and the estuary. It is well known that temperature can affect DO concentration by influencing biological and physical processes. Temperature can enhance oxygen consumption processes, i.e. respiration (Sampou \& Kemp 1994), but it can also intensify oxygen production processes, i.e. photosynthesis (Davison 1991). Furthermore, temperature can influence DO indirectly, through its effect on the strength of water-column stratification, which can affect water-column ventilation rates (Welsh \& Eller 1991). Our results showed clear axial differences in the dominant way in which temperature affects DO saturation in both estuaries. In the Bilbao estuary, the nega- tive association between water temperature and DO saturation and the absence of a significant relationship between chl $a$ and DO saturation at 30 salinity (Fig. 6f, Table 2) suggest that the main mode of influence of temperature is through the effect on DO consumption processes. The possible effect of temperature on DO saturation as a consequence of an enhancement of water-column stratification is considered to be negligible, given that in this estuarine zone the water column is highly salt-stratified throughout the year (see Table 1, Fig.2).

In contrast to findings in the inner zone, at the outer estuary of Bilbao (salinity $\geq 34$ ), chl a concentration was the only single variable to show a significant relationship with DO saturation (Fig. 6k, Table 2). This shows that in this zone, oxygen production processes have a stronger effect on DO-saturation dynamics than oxygen consumption processes. Close positive correlations between DO and primary production or chlorophyll concentration have been reported for some coastal waters (Bierman et al. 1994, Yoshikawa et al. 2007), and other lower estuarine zones have been shown to be net sources of oxygen through primary production (Moore et al. 2009). Given that a significant positive link between chl a concentration and water tempera-

Table 2. Structure of the statistically selected best models. The covariates (as opposed to the state variables) are in italics. Approximate significance of smoothed terms is given as p-values. For estimated degrees of freedom (edf) of the covariate under study, values of 1 indicate a linear effect and values > 1 show a progressively stronger non-linear effect. DOS: dissolved oxygen saturation, GAM: generalised additive model, GAMM: generalised additive mixed model

\begin{tabular}{|c|c|c|c|c|c|c|c|}
\hline Estuary & Salinity zone & Type of model & Model & edf & $\mathrm{p}$ & $\mathrm{R}_{\text {adj }}^{2}$ & $\mathrm{n}$ \\
\hline \multirow[t]{13}{*}{ Bilbao } & 30 & GAM & $\begin{array}{c}\text { Chl a s(water temperature) } \\
\text { water temperature }\end{array}$ & 1 & $<0.001$ & 0.475 & 94 \\
\hline & & GAMM & DOS s(water temperature) & & & & \\
\hline & & & water temperature & 1 & $<0.001$ & 0.290 & 94 \\
\hline & & GAMM & DOS S(river discharge) & & & & \\
\hline & & & river discharge & 1 & $<0.001$ & 0.201 & 94 \\
\hline & 33 & GAMM & Chl a s(water temperature) & & & & \\
\hline & & & water temperature & 1 & $<0.001$ & 0.381 & 117 \\
\hline & & GAMM & DOS s (water temperature) $+\mathrm{s}(\mathrm{chl} a)$ & & & & \\
\hline & & & water temperature & 1 & $\begin{array}{r}0.005 \\
-0.001\end{array}$ & 0.119 & 117 \\
\hline & $\geq 34$ & GAMM & Chl a s(water temperature) & & -0.001 & & \\
\hline & & & water temperature & 1 & $<0.001$ & 0.414 & 118 \\
\hline & & GAMM & $\operatorname{DOS} \sim \mathrm{S}(\mathrm{chl} a)$ & & & & \\
\hline & & & chl a & 1 & 0.001 & 0.10 & 118 \\
\hline \multirow{11}{*}{ Urdaibai } & 30 & GAMM & Chl $a \sim \mathrm{s}$ (water temperature) & & & & \\
\hline & & & $\begin{array}{c}\text { Water temperature } \\
\text { wate }\end{array}$ & 1 & $<0.001$ & 0.456 & 95 \\
\hline & & GAM & DOS s(water temperature) $+\mathrm{s}(\mathrm{chl} a)$ & & & & \\
\hline & & & water temperature & 3.53 & $<0.001$ & 0.344 & 95 \\
\hline & & & chla & 3.74 & $<0.001$ & & \\
\hline & & GAM & DOS s(river discharge) & & & & \\
\hline & & & river discharge & 4.41 & $<0.001$ & 0.286 & 96 \\
\hline & 33 & GAMM & Chl a s(water temperature) & & & & \\
\hline & & & water temperature & 1 & $<0.001$ & 0.355 & 116 \\
\hline & & GAM & DOS s (water temperature) & & & & \\
\hline & & & water temperature & 4.52 & 0.002 & 0.125 & 117 \\
\hline
\end{tabular}



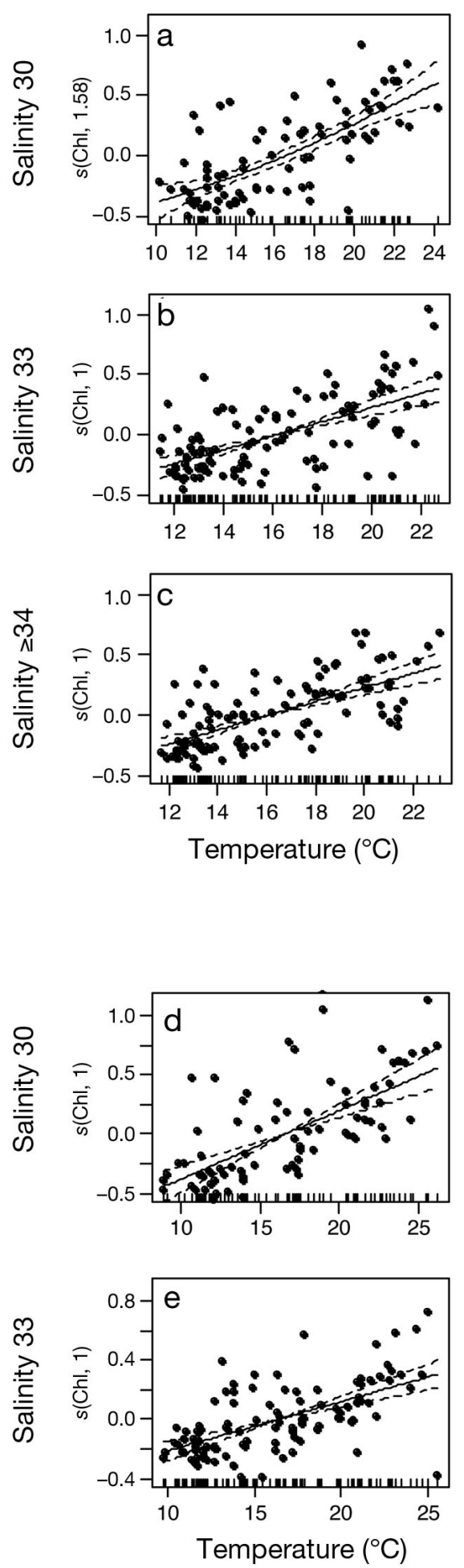
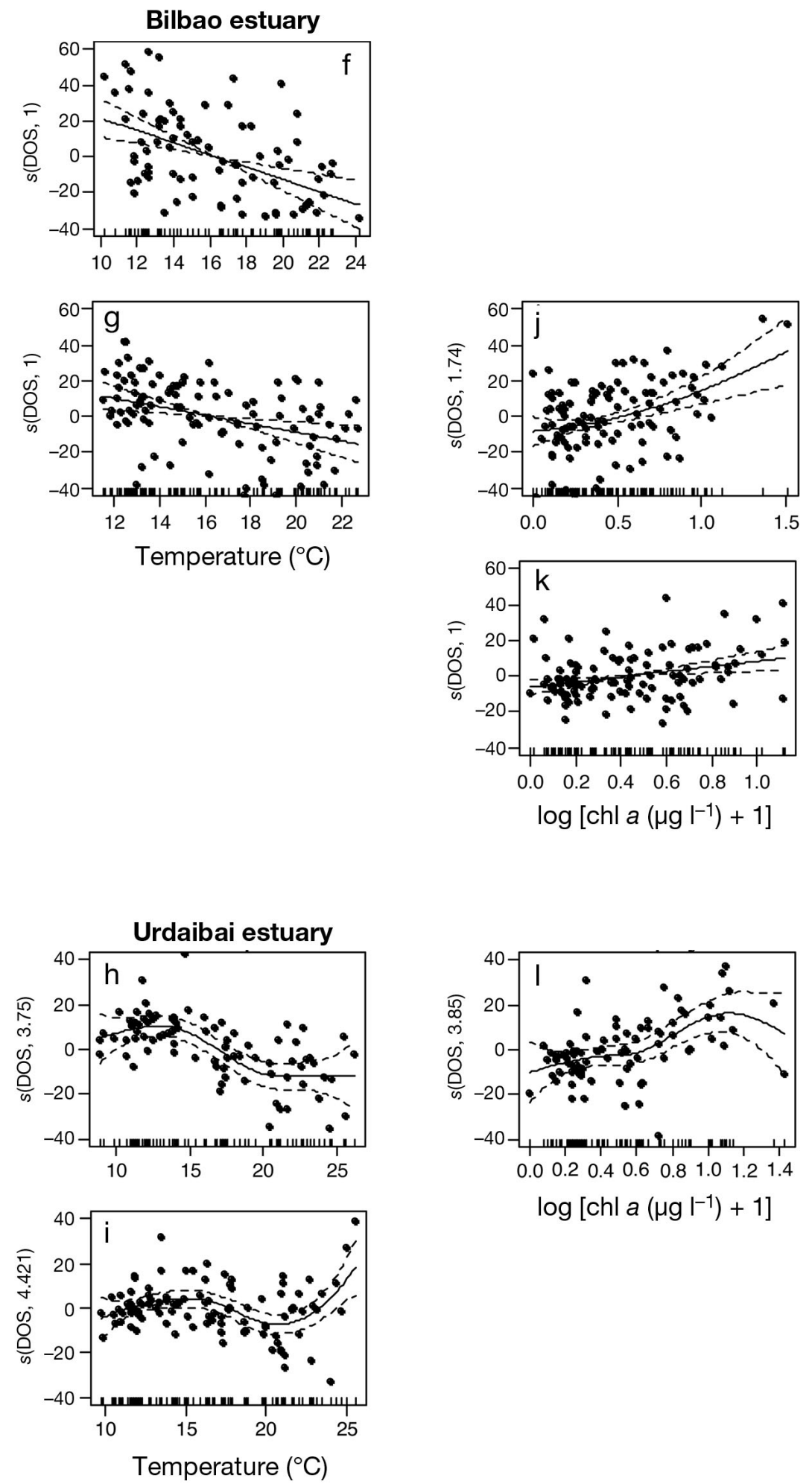

Fig. 6. Selected generalised additive models (GAMs) (or generalised additive mixed models, GAMMs, when necessary) for each of the 3 salinity zones in the Bilbao (upper panels) and Urdaibai (lower panels) estuaries. No models for Salinity $\geq 34$ in the Urdaibai estuary are shown because no statistically significant models were obtained. Effects of (a-e) water temperature on chl $a$, (f-i) water temperature on dissolved oxygen saturation (DOS) and (j-l) chl a on DOS. The $y$-axis values indicate the partial additive effect that the term on the $x$-axis has on the response variable. Numbers in parentheses on the $y$-axis indicate the estimated degrees of freedom (also used in Table 1). The final value of the response variable is given by the sum of all partial effects plus a constant. Broken lines show the 95\% (point-wise) confidence envelopes of the predicted curves. Short vertical lines located on the $x$-axes of each plot indicate the values at which observations were made 
ture was found for both estuaries and all salinity zones (Fig. 6a-e, Table 2) (except in the $\geq 34$ salinity zone of the Urdaibai estuary), it seems likely that in the outer estuary of Bilbao the positive influence of temperature on DO saturation was higher than the negative effect. In this estuary the intermediate zone of 33 salinity appears to be a transitional zone with regard to the main processes affecting DO saturation, since the statistical models captured significant associations both with temperature (negative effect) and chl a (positive effect) (Fig. 6g,j, Table 2). Here, the relationship of chl a with DO saturation was non-linear and suggests that the positive effect of chl a on DO saturation is only evident at high chl a levels, when autotrophic oxygen production exceeds oxygen consumption by heterotrophic processes. This inner-outer estuary gradient in the main mode of influence of temperature on DO saturation agrees well with the longitudinal pattern of plankton community metabolism and net ecosystem metabolism found in some estuaries, where a progression from a net heterotrophy in the inner estuary to a net autotrophy in the outer estuary has been observed at least during some periods of the year (Smith \& Kemp 1995, Caffrey 2003, Russell \& Montagna 2007). It can be hypothesised that in the outer waters, the system is more reliant on internal production of organic matter than on allochthonous sources (Caffrey 2003).

We also observed a longitudinal gradient in the way in which temperature affected DO saturation in the Urdaibai estuary. However, in some respects, this was slightly shifted in terms of salinity zones with respect to what we found in the Bilbao estuary. In the 30 salinity zone of the Urdaibai estuary, both a negative association with temperature and a positive one with chl a were observed (Fig. 6h,l, Table 2). These relationships were non-linear. The statistical model results showed that the negative effect of temperature was more marked in an intermediate range of temperatures, but

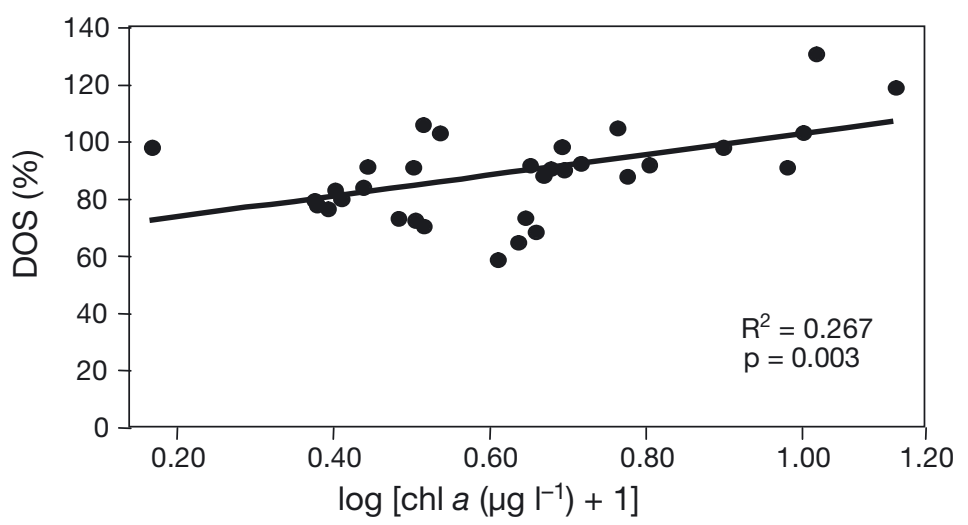

Fig. 7. Relationship between chl $a$ and dissolved oxygen saturation (DOS) at temperatures $>20^{\circ} \mathrm{C}$ in the 33 salinity zone of the Urdaibai estuary was weaker at high temperatures, which suggests that the effect of phytoplankton oxygen production on DOsaturation levels was stronger during the summer than during colder months. In the 33 salinity zone we can even see a positive effect of temperature on DO saturation at temperatures $>20^{\circ} \mathrm{C}$ (Fig. 6i), which suggests that temperature-enhanced photosynthetic oxygen production exceeds temperature-enhanced microbial oxygen consumption during the summer in this zone. In fact, although model results do not improve by adding chl a to temperature as an explanatory variable for DO-saturation variations, there was a significant correlation between chl $a$ and DO saturation at temperatures $>20^{\circ} \mathrm{C}$ (Fig. 7). Model results allow us to hypothesise the existence of a synergetic effect of the temperature-enhanced consumption and production of oxygen on DO-saturation variability also for the 30 salinity zone, where the enhancement of microbial consumption and photosynthetic production of oxygen would be balanced at temperatures $>20^{\circ} \mathrm{C}$ (Fig. 6h); the model also shows that the positive effect of $\mathrm{chl} a$ on DO saturation stops at the highest values obtained for the 30 salinity zone.

In the outer estuary (salinity $\geq 34$ ), neither water temperature nor chl a showed a significant relationship with DO saturation. In this outer zone of the Urdaibai estuary, the water column is well mixed (see Fig. 2) and tidal flushing is high (Villate et al. 1989). Therefore it can be hypothesised that physical factors such as the rate of water-column ventilation and residence time of tidal waters (not included in the analysis) have a stronger effect than biological processes of oxygen consumption and production. Low tidal-mixing energy has been shown to be a main driver of hypoxia even in non-eutrophic waters (Hagy \& Murrell 2007). In the intermediate zone of salinity 33 in the Urdaibai estuary, the statistical models revealed a sinusoid-like effect of water temperature (Fig. 6i, Table 2), which suggests that there are temperature ranges in which the effect of temperature on DO saturation is negative and others in which it is positive. Therefore, in contrast with observations for the Bilbao estuary, in the Urdaibai estuary the inner-outer gradient in the main mode of influence of temperature on DO saturation does not show that autotrophic processes replace heterotrophic processes in the control of DO-saturation dynamics. In the Urdaibai estuary, biological processes linked to temperature seem to be replaced by physical processes of tidal exchange and turbulence as the main mechanisms regulating DO saturation in the outer estuary.

An interesting finding was that the amount of DOsaturation variability accounted for by the additive models decreased from the inner to the outer salinity zones in both estuaries (Table 2). The total particulate 
organic matter and the organic content of sediments increase from the outer to the inner salinity zones of both estuaries, and the concentration of chl a also increases from the outer to the inner salinity zone in the Urdaibai estuary (Uriarte \& Villate 2004, Cotano \& Villate 2006, Villate et al. 2008). This indicates that the availability of respiratory substrates in water and sediments increases from the outer to the inner zone in both estuaries. In addition, water temperature fluctuations also increase from the $\geq 34$ salinity zone to the 30 salinity zone. All this suggests a greater contribution of the temperature-dependent metabolic processes to the DO-saturation dynamics inward from the mouth of the estuaries.

These results allow us to conclude that the inner zone of both estuaries, in comparison with the outer zones, are more sensitive to temperature-induced changes in DO saturation. In consequence, and for future scenarios of climate change in which global warming will affect DO in estuaries, the impact can be expected to be more severe in the inner stratified zones of these estuaries. Management strategies should aim to reduce as much as possible the availability of respiratory substrates in those areas.

\section{Effect of river discharge on DO saturation}

The statistical models showed a positive relationship of DO saturation with river discharge in the inner salinity zone of both estuaries (Fig. 8). The regression models revealed that for the estuary of Urdaibai this positive effect was strong in a narrow range of low river flows, but very weak at higher river flows. This indicates that here the effect of river discharge on DO saturation operates under conditions of very low river discharge, registered only in summer. Summer is the driest season on the Basque coast and, as a consequence, the surface low-salinity layer becomes thinner

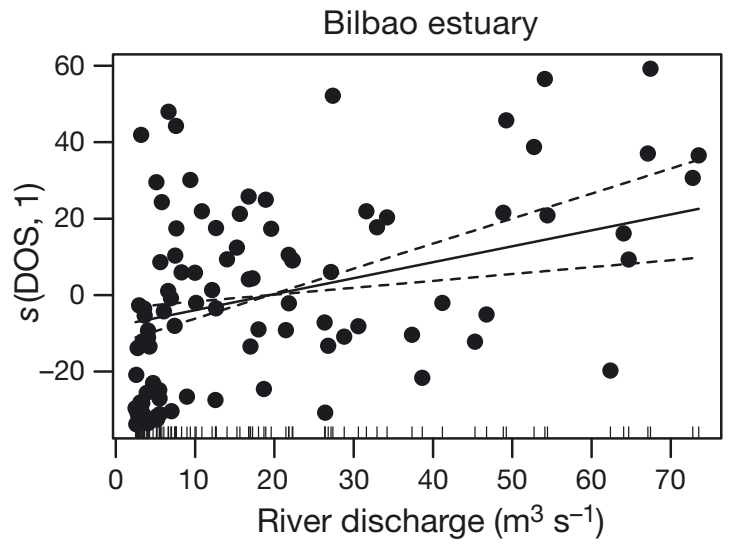

than during wetter months in the estuaries under study, but enough to maintain stratification in the midinner estuaries (except during very high freshwater flows in the inner estuaries). In addition, low river discharge causes water residence time to be longest during the summer (García-Barcina 2003) and this could limit DO replenishment in bottom waters in the inner zone. We thus suggest that the residence time of water becomes influential for DO saturation, but mainly at very low river flows.

The effect of river flow on DO levels can vary as a function of the hydrographical and climatic features of nearshore coastal and estuarine systems. For example, in the shallow lagoonal Pamlico River estuary (USA), where there is negligible tidal influence and dominance of wind and density-driven currents, hypoxic summers are characterised by frequent but moderate freshwater discharges that are accompanied by few wind-mixing events, whereas extremely high and low river flows with more frequent wind-mixing events do not cause summer hypoxia (Lin et al. 2008). In the northern Gulf of Mexico continental shelf adjacent to the outflows of the Mississippi and Atchafalaya Rivers, high river discharges, particularly river floods, cause an increase in the extent of hypoxia and low river discharges result in smaller areas of hypoxia (Rabalais et al. 2002). In the shallow 30 salinity zones of our estuaries, moderate to high river-discharge conditions ameliorate DO-saturation conditions relative to those registered under very low river flows during the summer, very likely due to improved flushing rates.

However, when we attempted to build a statistical model by adding the effect of the various possible driving factors, only the addition of temperature (Bilbao estuary) or the addition of temperature and chl a gave significant models for DO-saturation variations at the inner zone of both estuaries, the effect of river discharge being excluded from these models.

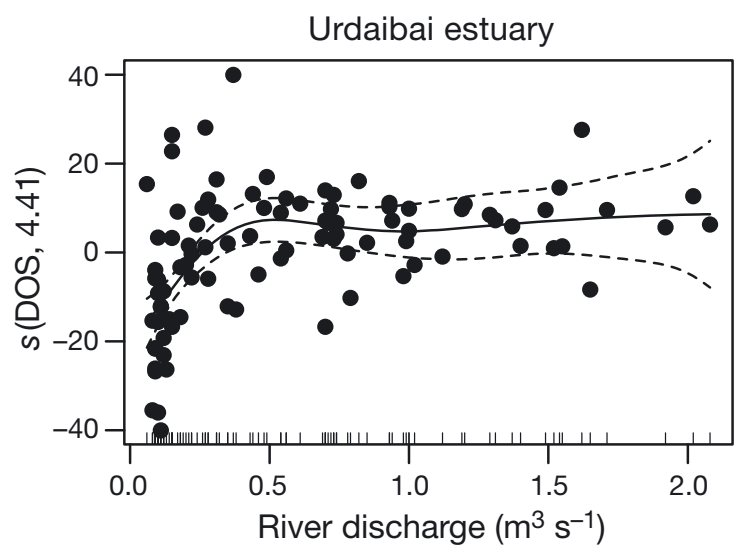

Fig. 8. Additive models of the effects of river discharge on dissolved oxygen saturation (DOS) at salinity 30 in the Bilbao (left) and Urdaibai (right) estuaries. Details as in Fig. 6 legend 


\section{CONCLUSIONS}

Spatial and temporal variations in DO saturation, and the current severity and extent of hypoxia were higher in the culturally eutrophicated and stratified Bilbao estuary than in the shallower and less perturbed Urdaibai estuary. The seasonal patterns of DO saturation and the hierarchy of factors controlling them differed largely both between estuaries and between salinity zones. In the Bilbao estuary, temperature was the main factor responsible for the seasonal changes in DO saturation and the development of hypoxia below the halocline in the inner stratified waters (30 salinity), by enhancing oxygen consumption processes. However, normoxic conditions and a seasonal pattern of DO saturation mainly accounted for by the autotrophic production of oxygen were observed in the outer waters ( $\geq 34$ salinity) of this estuary. In the Urdaibai estuary, DO saturation was influenced by the combined effects of autotrophic and heterotrophic processes related to temperature in the inner waters (30 salinity), and remained rather constant and close to $100 \%$ saturation in the outer waters ( $\geq 34$ salinity). This outer-estuary pattern is likely due to the effect of physical processes such as turbulence and tidal exchange. River discharge affected DO saturation only at the inner waters (30 salinity) of both estuaries, with results showing that DO saturation decreased under conditions of low river discharge. However, when the effect of several variables on DO-saturation variability was tested in an additive mode, the statistical models excluded river discharge, and only water temperature and $\mathrm{chl}$ a were selected as explicative factors. The effects of temperature-dependent processes on DO-saturation dynamics, however, decreased from the inner to the outer salinity zones of both estuaries. The inner waters of the Urdaibai estuary were found to be the most sensitive to temperature-dependent changes in DO saturation, whereas no effects were detected in the well-flushed, high-salinity zone of this estuary.

Acknowledgements. This research was funded by the United Nations Educational, Scientific and Cultural Organization (UNESCO) Chair on 'Sustainable Development and Environmental Education' (UNESCO03/04), the University of the Basque Country (EHU06/52) and the Basque Government (ETORTEK07/25). G.A. was supported by the funding programme for the improvement of the research output of young postdoctoral scientists of the University of the Basque Country. M.L. thanks the Marie Curie Intra-European fellowship for funding (FP6-2005-Mobility-5, European Commission). We thank the County Council of Bizkaia for providing hydro-meteorological data.

\section{LITERATURE CITED}

Aravena G, Villate F, Iriarte A, Uriarte I, Ibáñez B (2009) Influence of the North Atlantic Oscillation (NAO) on climatic factors and estuarine water temperature on the Basque coast (Bay of Biscay): comparative analysis of three seasonal NAO indices. Cont Shelf Res 29:750-758

Belzunce MJ, Solaun O, Valencia V, Pérez V (2004) Contaminants in estuarine and coastal waters. In: Borja A, Collins $M$ (eds) Oceanography and marine environment of the Basque Country. Elsevier Oceanography Series 70. Elsevier, Amsterdam, p 233-251

Bierman VJ, Hinz SC, Zhu DW, Wiseman WJ, Rabalais NN, Turner RE (1994) A preliminary mass balance model of primary productivity and dissolved oxygen in the Mississippi River plume/Inner Gulf Shelf Region. Estuaries 17: 886-899

> Borja A, Muxika I, Franco J (2006) Long-term recovery of softbottom benthos following urban and industrial sewage treatment in the Nervión estuary (southern Bay of Biscay). Mar Ecol Prog Ser 313:43-55

Borsuk ME, Stow CA, Luettich RA Jr, Paerl HW, Pinckney JL (2001) Modelling oxygen dynamics in an intermittently stratified estuary: estimation of process rates using field data. Estuar Coast Shelf Sci 52:33-49

Boynton WR, Kemp WM, Keefe CW (1982) A comparative analysis of nutrients and other factors influencing phytoplankton production. In: Kennedy VS (ed) Estuarine comparisons. Academic Press, New York, NY, p 69-90

Breitburg DL, Adamack A, Rose K, Kolesar SE and others (2003) The pattern and influence of low dissolved oxygen in the Patuxent River, a seasonally hypoxic estuary. Estuaries 26:280-297

Butrón A, Iriarte A, Madariaga I (2009) Size-fractionated phytoplankton biomass, primary production and respiration in the Nervión-Ibaizabal estuary: a comparison with other nearshore coastal and estuarine systems from the Bay of Biscay. Cont Shelf Res 29:1088-1102

Buzzelli CP, Luettich RA Jr, Powers S, Peterson CH, McNinch JE, Pinckney JL, Paerl HW (2002) Estimating the spatial extent of bottom-water hypoxia and habitat degradation in a shallow estuary. Mar Ecol Prog Ser 230:103-112

> Caffrey JM (2003) Production, respiration and net ecosystem metabolism in U.S. estuaries. Environ Monit Assess 81: $207-219$

Cloern JE, Jassby AD (2008) Complex seasonal patterns of primary producers at the land-sea interface. Ecol Lett 11: 1294-1303

- Cotano U, Villate F (2006) Anthropogenic influence on the organic fraction of sediments in two contrasting estuaries: a biochemical approach. Mar Pollut Bull 52:404-414

> Davison IR (1991) Environmental effects on algal photosynthesis: temperature. J Phycol 27:2-8

> Diaz RJ (2001) Overview of hypoxia around the world. J Environ Qual 30:275-281

Franco J, Ruiz A, Orive E (1996) Escalas y factores de variabilidad del oxígeno disuelto en el estuario de Urdaibai. Ozeanografika 1:43-64

Franco J, Borja A, Valencia V (2004) Overall assessmenthuman impacts and quality status. In: Borja A, Collins M (eds) Oceanography and marine environment of the Basque Country. Elsevier Oceanography Series 70. Elsevier, Amsterdam, p 581-597

García-Barcina JM (2003) Estimación del tiempo de residencia en el estuario del Nervión y de su capacidad de dilución mediante modelización matemática. Technical report. Consorcio de Aguas Bilbao Bizkaia, Bilbao

> García-Barcina JM, González-Oreja JA, De la Sota A (2006) Assessing the improvement of the Bilbao estuary water quality in response to pollution abatement measures. Water Res 40:951-960 
Gómez V, Maravall A (1994) Estimation, prediction, and interpolation for nonstationary series with the Kalman filter. J Am Stat Assoc 89:611-624

Gómez V, Maravall A, Pena D (1999) Missing observations in ARIMA models: skipping approach versus additive outlier approach. J Econometr 88:341-363

González-Oreja JA, Saiz-Salinas JI (1998) Exploring the relationships between abiotic variables and benthic community structure in a polluted estuarine system. Water Res 32:3799-3807

> Hagy JD, Murrell MC (2007) Susceptibility of a northern Gulf of Mexico estuary to hypoxia: an analysis using box models. Estuar Coast Shelf Sci 74:239-253

Hastie TJ, Tibshirani RJ (1990) Generalized additive models. Routledge, Chapman \& Hall, New York, NY

Howarth RW, Swaney DP, Butler TJ, Marino R (2000) Climatic control on eutrophication of the Hudson River estuary. Ecosystems 3:210-215

Iriarte A, de Madariaga I, Diez-Garagarza F, Revilla M, Orive E (1996) Primary plankton production, respiration and nitrification in a shallow temperate estuary during summer. J Exp Mar Biol Ecol 208:127-151

> Iriarte A, de la Sota A, Orive E (1998) Seasonal variation of nitrification along a salinity gradient in an urban estuary. Hydrobiologia 362:115-126

Jeffrey SW, Mantoura RFC (1997) Development of pigment methods for oceanography: SCOR-supported Working Groups and objectives. In: Jeffrey SW, Mantoura RFC, Wright SW (eds) Phytoplankton pigments in oceanography: guidelines to modern methods. UNESCO, Paris, p 19-36

Kemp WM, Sampou PA, Garber J, Tuttle J, Boynton WR (1992) Seasonal depletion of oxygen from bottom waters of Chesapeake Bay: roles of benthic and planktonic respiration and physical exchange processes. Mar Ecol Prog Ser 85:137-152

Kemp WM, Testa JM, Conley DJ, Gilbert D, Hagy JD (2009) Coastal hypoxia responses to remediation. Biogeosci Discuss 6:6889-6948

Kuo AY, Park K, Moustafa MZ (1991) Spatial and temporal variability of hypoxia in the Rappahannock River, Virginia. Estuaries 14:113-121

Lin J, Xu H, Cudaback C, Wang D (2008) Inter-annual variability of hypoxic conditions in a shallow estuary. J Mar Syst 73:169-184

Moore TS, Nuzzio DB, Di Toro DM, Luther GW (2009) Oxygen dynamics in a well mixed estuary, the lower Delaware Bay, USA. Mar Chem 117:11-20

Nezlin NP, Kamer K, Hyde J, Stein ED (2009) Dissolved oxygen dynamics in a eutrophic estuary, Upper Newport Bay, California. Estuar Coast Shelf Sci 82:139-151

Paerl HW, Pinckney JL, Fear JM, Peierls BL (1998) Ecosystem responses to internal watershed organic matter loading: consequences for hypoxia in the eutrophying Neuse River Estuary, North Carolina, USA. Mar Ecol Prog Ser 166: $17-25$

Park K, Kim CK, Schroeder WW (2007) Temporal variability in summertime bottom hypoxia in shallow areas of Mobile Bay, Alabama. Estuar Coast 30:54-65

Rabalais NN, Turner RE, Wiseman WJ Jr (2002) Gulf of Mexico hypoxia, a.k.a. 'the dead zone'. Annu Rev Ecol Syst 33:235-263

Editorial responsibility: Hans Heinrich Janssen, Oldendorf/Luhe, Germany
Russell MJ, Montagna PA (2007) Spatial and temporal variability and drivers of net ecosystem metabolism in western Gulf of Mexico estuaries. Estuar Coast 30:137-153

Sampou P, Kemp WM (1994) Factors regulating plankton community respiration in Chesapeake Bay. Mar Ecol Prog Ser 110:249-258

Smith EM, Kemp WM (1995) Seasonal and regional variations in plankton community production and respiration for Chesapeake Bay. Mar Ecol Prog Ser 116:217-231

Uriarte I, Villate F (2004) Effects of pollution on zooplankton abundance and distribution in two estuaries of the Basque coast (Bay of Biscay). Mar Pollut Bull 49:220-228 doi:10.1016/j.marpolbul.2004.02.010

Urrutia J (1986) Estudio de la estructura y funcionamiento del estuario del Nervión en relación a la dinámica del fitoplancton. PhD thesis, Universidad del País Vasco, Bizkaia Campus

Usabiaga JI, Sáenz-Aguirre J, Valencia V, Borja A (2004) Climate and meteorology, variability and its influence on the ocean. In: Borja A, Collins M (eds) Oceanography and marine environment of the Basque Country. Elsevier Oceanography Series 70. Elsevier, Amsterdam, p 75-95

Valencia V, Franco J (2004) Main characteristics of the water masses. In: Borja A, Collins M (eds) Oceanography and marine environment of the Basque Country. Elsevier Oceanography Series 70. Elsevier, Amsterdam, p 197-232

Valencia V, Franco J, Borja A, Fontán A (2004) Hydrography of the southeastern Bay of Biscay. In: Borja A, Collins $M$ (eds) Oceanography and marine environment of the Basque Country. Elsevier Oceanography Series 70. Elsevier, Amsterdam, p 159-194

Verity PG, Alber M, Bricker SB (2006) Development of hypoxia in well-mixed subtropical estuaries in the southeastern USA. Estuar Coast 29:665-673

Villate F, Franco J, Ruiz A (1989) Caracterización geomorfológica e hidrológica de cinco sistemas estuáricos del País Vasco. Kobie 18:157-170

Villate F, Aravena G, Iriarte A, Uriarte I (2008) Axial variability in the relationship of chlorophyll a with climatic factors and the North Atlantic Oscillation in a Basque coast estuary, Bay of Biscay (1997-2006). J Plankton Res 30:1041-1049

Welsh BL, Eller FC (1991) Mechanisms controlling summertime oxygen depletion in western Long Island Sound. Estuaries 14:265-278

> Wiseman WJ Jr, Rabalais NN, Turner RE, Dinnel SP, MacNaughton A (1997) Seasonal and interannual variability within the Louisiana Coastal Current: stratification and hypoxia. J Mar Syst 12:237-248

Wood SN (2000) Modelling and smoothing parameter estimation with multiple quadratic penalties. J R Stat Soc B 62: $413-428$

Wood SN (2006) Generalized additive models: an introduction with R. Chapman \& Hall/CRC, Boca Raton, FL

Yoshikawa T, Murata O, Furuya K, Eguchi M (2007) Shortterm covariation of dissolved oxygen and phytoplankton photosynthesis in a coastal fish aquaculture site. Estuar Coast Shelf Sci 74:515-527

Zuur A, Ieno E, Smith G (2007) Analysing ecological data. Springer, New York, NY

Submitted: July 28, 2009; Accepted: September 7, 2010

Proofs received from author(s): November 1, 2010 